ISSN: 1858-4837; E-ISSN: 2598-019X

Volume 15, Nomor 2 (2020),

https://jurnal.uns.ac.id/region

DOI: 10.20961/region.v16i1.38451

\title{
Kerangka kerja penilaian rencana tata ruang berbasis manajemen risiko bencana
}

\section{Framework for spatial plan assessment based on disaster risk management}

\author{
S G Rozita ${ }^{1,2}$, R Setiadi ${ }^{1}$ \\ ${ }^{1}$ Urban and Regional Planning, Faculty of Engineering, Diponegoro University \\ ${ }^{2}$ Aceh's Public Housing And Settlement Department
}

Corresponding author's email: gieta.oji@gmail.com

\begin{abstract}
Abstrak. Sistem regulasi di Indonesia mengamanatkan untuk memasukkan pertimbangan kebencanaan dalam penyusunan rencana tata ruang. Namun demikian belum ada panduan yang terintegrasi untuk menerjemahkan konsep manajemen risiko bencana ke dalam rencana tata ruang. Studi ini bertujuan untuk merumuskan kerangka kerja untuk memadukan konsep manajemen risiko bencana (MRB) ke dalam rencara tata ruang sehingga dapat dijadikan panduan dalam penilaian produk tata ruang. Metode yang digunakan ialah deskriptif kualitatif, dengan menggunakan sumber data sekunder berupa literatur sebagai data utamanya. Penelitian ini menghasilkan tabel kerangka kerja yang berfungsi sebagai pedoman untuk menilai penerapan konsep MRB dalam menyusun rencana tata ruang. Studi ini menemukan bahwa tidak semua komponen dari MRB dapat masuk ke dalam ranah perencanaan tata ruang, terutama untuk komponen yang terkait dengan tahapan respon bencana.
\end{abstract}

Kata Kunci: Kerangka Kerja; Manajemen Risiko Bencana; Tata Ruang

\begin{abstract}
The regulatory system in Indonesia mandates to include disaster considerations in the spatial plans drafting. However, there is no inegrated guide to interpret the concept of disaster risk management into spatial planning. This study aims to formulate a framework for integrating the concept of disaster risk management (DRM) into spatial planning so that it can be used as a guide in the assessment of spatial products. The method used is descriptive qualitative, using secondary data sources in the form of literature as the main data. This study results a framework table that serves as a guide for assessing the application of the DRM
\end{abstract}


concept in drafting spatial plans. This study found that not all components of DRM can enter the spatial planning domain, especially for components related to the disaster response stage.

Keywords: Disaster Risk Management; Framework; Spatial Planning

\section{Pendahuluan}

Indonesia menjadi salah satu negara yang banyak mengalami bencana alam. Hal ini disebabkan oleh letak geografis [1,2], pengaruh perubahan cuaca ekstrim [3] serta diiringi oleh semakin meningkatnya populasi yang memberi tekanan pada lingkungan fisik $[4,5]$. Pengelolaan terhadap bencana dengan tujuan mengurangi risiko dan korban bencana menjadi suatu hal yang mendesak, dalam hal ini penataan ruang diyakini sebagai salah satu instrumen yang berperan penting [6-11]. Salah satu peran rencana tata ruang dalam mengurangi risiko bencana dapat melalui pengaturan pola ruang dan struktur ruang sehingga meningkatkan kapasitas suatu wilayah dan mengurangi kerentanan masyarakatnya [12]. Guna memenuhi perannya tersebut, perumusan rencana penggunaan lahan atau rencana tata ruang dapat dilakukan dengan memasukkan atau mengintegrasikan berbagai strategi dari konsep manajemen risiko bencana (MRB), khususnya pengurangan risiko bencana [13-15].

MRB merupakan suatu proses pengelolaan yang sistematis dan terencana terkait penerapan strategi dan kebijakan penanggulangan bencana, dimana terdapat penekanan pada aspekaspek pengurangan risiko bencana [16]. Di dalamnya terdapat beberapa komponen yaitu manajemen bencana dan pengurangan risiko bencana dengan turunan menjadi empat upaya utama yaitu mitigasi, kesiapsiagaan, respon, dan pemulihan [17,18]. Menjadikan upaya pengurangan risiko bencana dan manajemen bencana sebagai prioritas dalam perencanaan dan program pembangunan pada berbagai tingkatan pemerintahan baik pada level pemerintah pusat, provinsi, maupun kabupaten/ kota merupakan hal yang penting dilakukan [8].

Penelitian tentang integrasi konsep MRB dalam rencana tata ruang telah banyak dilakukan [8,19-23], namun sebagian besar hanya fokus pada penilaian tingkat risiko bencana dan kesesuaian penggunaan lahan. Sumbangan pemahaman kebencanaan lebih banyak difokuskan pada pemetaan kawasan rawan bencana, baik sebagai dasar perencanaan guna lahan maupun sebagai alat evaluasi kebijakan. Disisi lain, bagaimana hasil kajian risiko bencana dapat masuk ke dalam setiap jenjang perencanaan sehingga penerapannya dapat lebih operasional belum sepenuhnya diatur dan belum memiliki petunjuk baku, yang dapat diartikan belum ada upaya lebih lanjut untuk menerjemahkan konsep MRB sehingga benarbenar dapat digunakan sebagai dasar penyusunan pada setiap substansi rencana tata ruang [24]. Hal ini dapat mengakibatkan rendahnya kemampuan perencana dalam menuangkan konsep risiko bencana dalam produk perencanaan, dimana diperlukan transfer dari informasi kebencanaan ke dalam bahasa perencanaan tata ruang [25]. 
Oleh karena itu, perlu adanya sebuah kerangka kerja yang dapat dijadikan panduan dalam memadukan konsep pengelolaan bencana yang dikenal dengan MRB (berdasarkan Kerangka Kerja Sendai) dengan kebijakan rencana tata ruang. Diharapkan kerangka kerja ini dapat digunakan untuk melakukan penilaian terhadap substansi produk rencana tata ruang terkait MRB.

\section{Metode}

Metode yang digunakan yaitu kualitatif deskriptif dengan penyajian hasil dalam bentuk tabel matrik dan deskripsi. Studi ini bersifat library research yaitu dengan melakukan sintesis terhadap berbagai literatur. Pada tahap pertama, kajian teoritis mengenai konsep MRB dari berbagai sumber penelitian dikumpulkan dan disarikan, terutama mengenai bentuk-bentuk tindakan atau strategi dari setiap aktivitas MRB yang terkait dengan substansi penataan ruang. Lingkup substansi literatur yang dijadikan acuan cukup beragam, meliputi pengertian dasar manajemen risiko bencana beserta berbagai aktivitasnya (mitigasi, kesiapsiagaan, respon, dan pemulihan), pedoman penanggulangan bencana di beberapa negara seperti Amerika dan Jepang, kajian hubungan kebencanaan dengan perencanaan penggunaan lahan yang dilakukan di beberapa negara seperti Eropa dan China, serta berbagai kajian upaya penanggulangan bencana sesuai jenis bencana tertentu seperti tsunami, gempa bumi, dan banjir. Berbagai informasi yang didapatkan tersebut, kemudian dikelompokkan sesuai jenis aktivitas MRB, yaitu mitigasi, kesiapsiagaan, respon, dan pemulihan. Pengelompokkan ini disesuaikan dengan pengertian dari masing-masing aktivitas MRB tersebut, sehingga terlihat perbedaan pada setiap fasenya. Selanjutnya, hasil pengelompokan ini juga diklasifikasikan sesuai tema standar muatan dalam produk rencana tata ruang, yaitu strategi perencanaan, struktur ruang, pola ruang, penetapan kawasan strategis, arahan pemanfaatan ruang serta pengendalian pemanfaatan ruang. Hal ini tentu dilakukan melalui langkah penyesuaian lingkup pengaturan dari masing-masing tema tersebut. Klasifikasi ini berguna sebagai acuan dalam menerjemahkan konsep MRB ke dalam lingkup tata ruang.

Kedua, kajian literatur selanjutnya diarahkan untuk melihat bentuk penataan ruang yang seharusnya dilakukan pada setiap skala keruangan (makro, meso, dan mikro). Seperti diketahui, terdapat jenjang perencanaan dengan lingkup dan skala wilayah administratif yang berbeda-beda. Variasi skala ini mempengaruhi kedalaman substansi yang diatur. Penentuan kedalaman strategi dan bentuk penataan ruang yang terdapat pada masingmasing level perencanaan didasari oleh pedoman penyusunan rencana tata ruang yang berlaku di Indonesia, mulai dari pedoman penyusunan RTRW Provinsi, RTRW Kabupaten/ Kota, sampai RDTR, serta meninjau RTRW Nasional. Adapun skala keruangan di Indonesia dapat disistematiskan melalui Gambar 1, sedangkan secara keseluruhan tahapan dalam merumuskan kerangka kerja lebih jelas dapat dilihat pada Gambar 2.

Metode dalam pengembangan kerangka kerja ini lebih difokuskan pada bahaya tsunami, gempa bumi, dan banjir, sebagai bahaya yang banyak mengancam kota-kota pantai di Indonesia, walaupun letusan gunung berapi, lonjakan badai dan tanah longsor juga merupakan beberapa potensi bahaya lain yang relevan dengan rencana tata ruang [29]. 


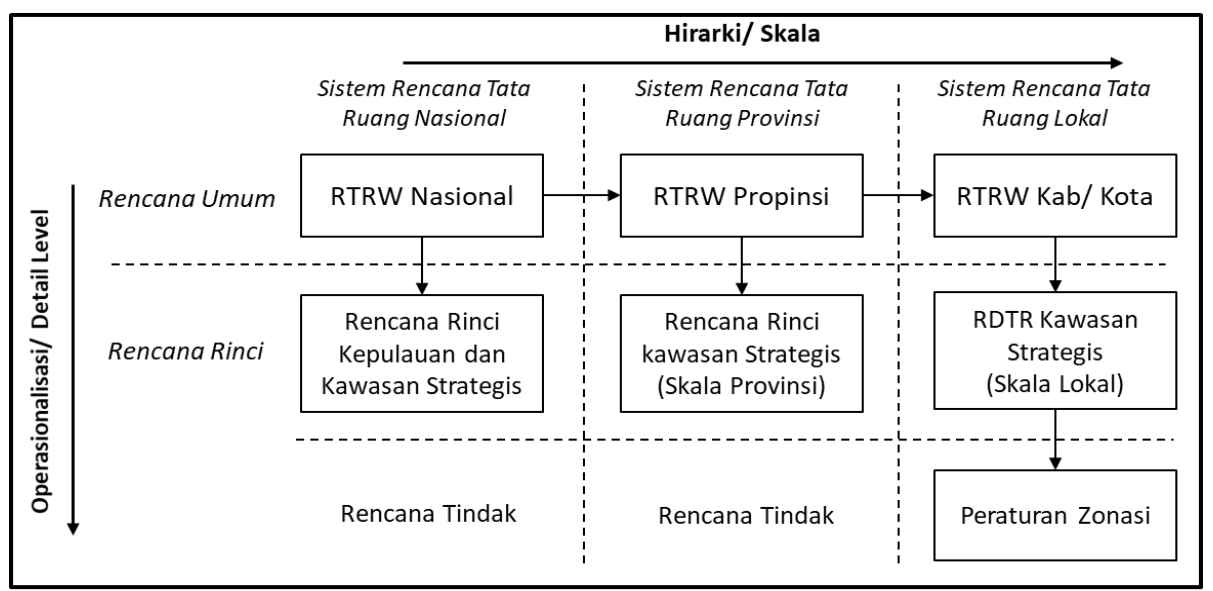

Gambar 1. Sistem perencanaan tata ruang di Indonesia berdasarkan UUPR No.26 tahun 2007 [31].

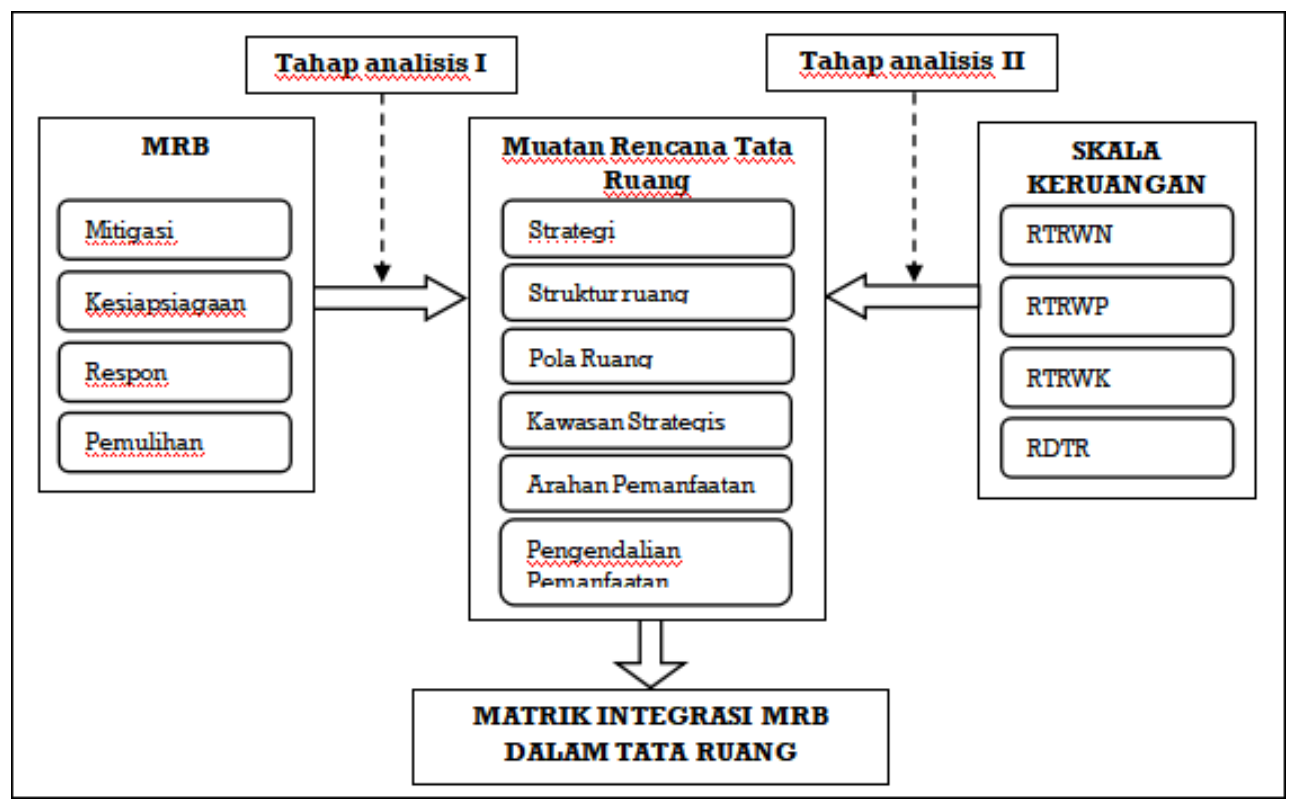

Gambar 2. Alur perumusan kerangka kerja.

\section{Hasil penelitian dan pembahasan}

Setelah melakukan tahap analisis pertama, maka dihasilkan tabel rumusan literatur MRB yang sesuai dengan muatan rencana tata ruang. Berdasarkan Tabel 1 tersebut, dapat disimpulkan empat hal yang menjadi temuan.

Pertama, sebagian besar literatur mengenai MRB yang ada lebih banyak berada pada aspek arahan pemanfaatan ruang (kolom E). Hal ini terlihat dari banyaknya contoh-contoh bentuk konsep MRB yang diberikan dari berbagai sumber literatur, seperti pembangunan tanggul, jalur evakuasi, perbaikan sistem drainase, dan lain sebagainya. Bentuk-bentuk keruangan tersebut dapat ditempatkan pada ranah tata ruang dalam program keruangan yang 
diakomodir pada aspek arahan pemanfaatan ruang. Selain itu, mengingat arahan pemanfaatan ruang ialah wadah perwujudan struktur dan pola ruang, sehingga tentu saja berbagai konsep rencana dari kedua aspek ini akan termuat dalam arahan pemanfaatan ruang yang mengakibatkan lebih beragamnya penerjemahan MRB yang dihasilkan.

Aspek lain yang juga dapat memuat banyak konsep MRB dari berbagai sumber literatur ialah struktur ruang dan diikuti oleh strategi penataan ruang. Struktur ruang sebagai bentuk pengaturan sistem infrastruktur tentu menjadi dasar yang sangat baik dalam penerapan konsep MRB, dimana sebagian besar bentuk penerapan MRB terletak pada penguatan infrastruktur. Begitu juga dengan strategi penataan ruang. Sebagian besar literatur mengenai MRB pasti menyinggung mengenai pentingnya menghindari daerah rawan bencana dalam menentukan arah perkembangan pembangunan. Sebagai contoh seperti yang diungkapkan oleh Coburn, et al. [32], Edyanto [2], dan Saunders \& Kilvington [33], dimana ketiganya menyatakan perlunya menghindari atau membatasi pembangunan pada dataran yang berpotensi bahaya dan mendorong pertumbuhan pada daerah yang aman. Jika dikaitkan dengan muatan rencana tata ruang, hal ini berada pada bagian strategi penataan ruang yang merupakan pijakan dasar bagi penetapan rencana-rencana lainnya.

Kedua, pada Tabel 1 juga terlihat bahwa penetapan kawasan strategis adalah yang paling sedikit dibicarakan. Pada prinsipnya, penetapan kawasan strategis jika dilihat dari kacamata potensi bahaya tentu juga harus menghindari pemilihan kawasan yang rawan bencana sebagai kawasan strategis. Seperti diketahui kawasan strategis akan menjadi kawasan yang lebih cepat berkembang dan memiliki tarikan aktivitas yang tinggi. Oleh karena itu, faktor bahaya bencana harus menjadi dasar pertimbangannya. Namun, hal ini tidak banyak disinggung dalam berbagai literatur, mengingat lingkup kawasan strategis yang lebih spesifik pada faktor ekonomi.

Ketiga, dapat terlihat bahwa tidak ada satu sumber literatur pun yang mencakup keseluruhan muatan rencana tata ruang, bahkan tidak sedikit yang hanya membahas satu aspek saja. Dari sini dapat diungkapkan bahwa belum ada peneliti yang melihat secara komprehensif ketika menerapkan permasalahan kebencanaan dalam ranah tata ruang. Padahal pentingnya peran tata ruang dalam mengurangi risiko bencana telah diakui, namun tidak diikuti oleh pemahaman yang menyeluruh. Hal ini juga dapat dikaitkan dengan perbedaan sistem tata ruang di berbagai negara, sehingga lingkup yang ada pada tata ruang di Indonesia tidak semuanya dibicarakan oleh para peneliti. Sumber-sumber literatur yang cukup banyak dapat diserap materinya ke dalam muatan tata ruang yaitu Coburn, et al. [32] dan Barton [34].

Keempat, tidak terdapat juga sumber yang mencakup keempat komponen MRB yang dapat dikaitkan dengan tata ruang. Sebagian besar lebih fokus pada komponen mitigasi saja, mengingat komponen ini yang sangat sesuai dengan prinsip dasar rencana tata ruang yang bersifat proaktif terhadap bahaya bencana. Berbeda halnya dengan komponen MRB yang bersifat reaktif terhadap bencana seperti respon, belum dapat ditemukan sumber literatur yang mengaitkan berbagai tindakan respon bencana dengan muatan rencana tata ruang. 
Pada komponen kesiapsiagaan dan pemulihan juga hanya terdapat sedikit materi yang dapat dihubungkan dengan muatan rencana tata ruang. Kompilasi dari berbagai sumber mengenai konsep MRB yang terkait tata ruang dapat dilihat lebih jelas pada Tabel 1.

Tabel 1. Konsep MRB terkait tata ruang.

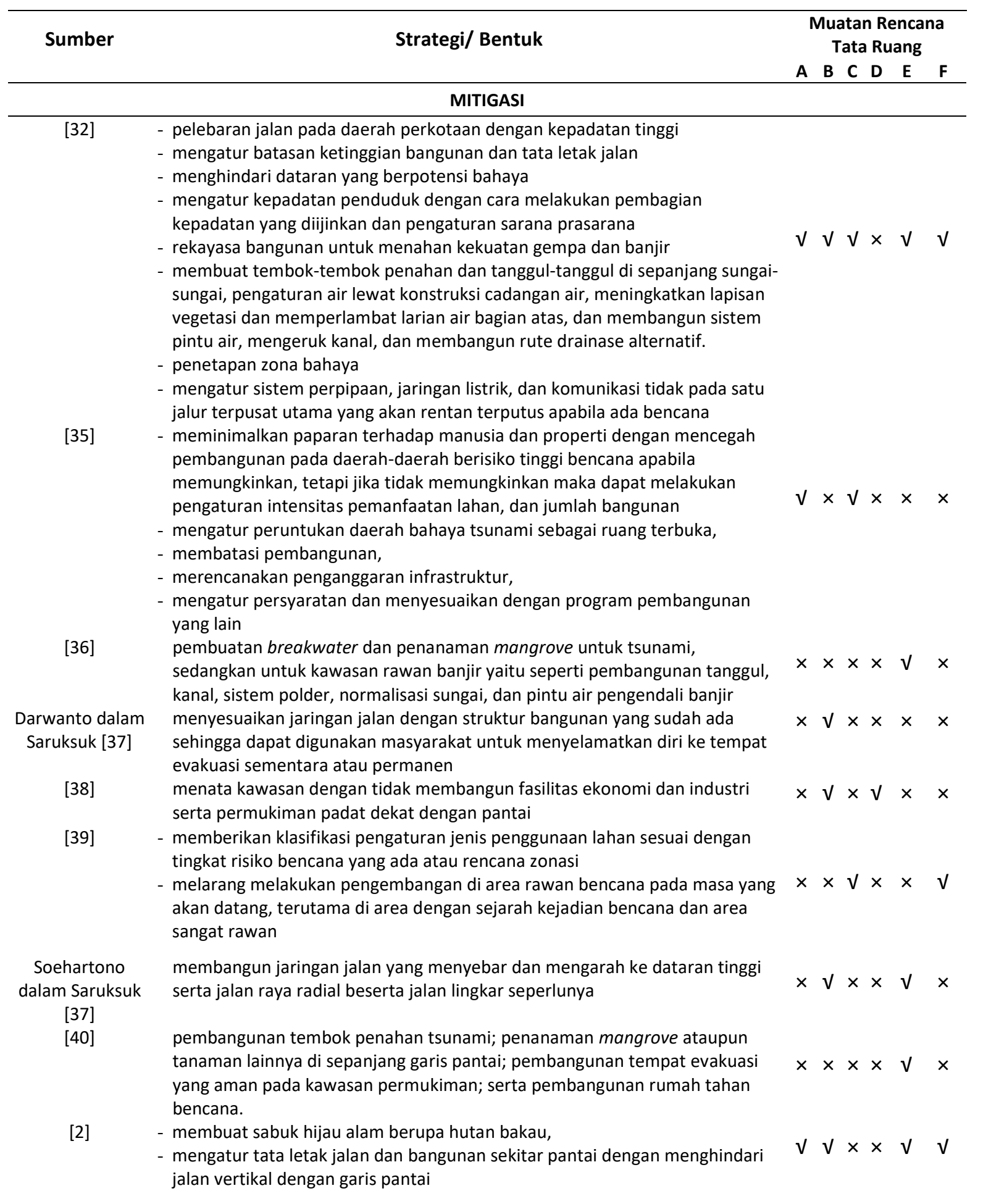




\begin{tabular}{|c|c|c|c|c|c|c|c|}
\hline \multirow[t]{2}{*}{ Sumber } & \multirow[t]{2}{*}{ Strategi/ Bentuk } & \multicolumn{6}{|c|}{$\begin{array}{l}\text { Muatan Rencana } \\
\text { Tata Ruang }\end{array}$} \\
\hline & & A & B & C & D & $E$ & $\mathbf{F}$ \\
\hline$[41]$ & $\begin{array}{l}\text { - memperkuat bangunan dengan membuat kode bangunan, desain rekayasa } \\
\text { - membangun bangunan penahan longsor, penahan dinding pantai, dan lain- } \\
\text { lain } \\
\text { - membangun pada lokasi yang menghindari/ menjauhi wilayah bencana } \\
\text { - membuat perencanaan penggunaan lahan dan manajemen penggunaan } \\
\text { lahan } \\
\text { - pembuatan tanggul, bendungan, bendungan pengendali sedimen, dan } \\
\text { perbaikan sistem drainase. }\end{array}$ & $\mathrm{V}$ & $x$ & $\times>$ & $x$ & $\sqrt{ }$ & $x$ \\
\hline$[42]$ & $\begin{array}{l}\text { - menetapkan daerah yang paling rawan tsunami sebagai sabuk hijau atau } \\
\text { ruang terbuka } \\
\text { - mengembangkan pembatasan baru pada lokasi berbahaya }\end{array}$ & $\mathrm{V}$ & $x$ & $\times$ & $x$ & $x$ & $x$ \\
\hline$[33]$ & $\begin{array}{l}\text { - pembatasan pengembangan di daerah yang berbahaya dan mendorong } \\
\text { - mertumbuhan pada daerah yang aman }\end{array}$ & $\mathrm{V}$ & $x$ & $\times$ & V & $x$ & $\sqrt{ }$ \\
\hline$[43]$ & $\begin{array}{l}\text { menentukan building codes dan pembatasan pembangunan pada kawasan } \\
\text { risiko tinggi bencana. }\end{array}$ & $x$ & $\times$ & $x$ & $x$ & $x$ & V \\
\hline$[44]$ & $\begin{array}{l}\text { mengatur garis multi perlindungan berturut-turut yaitu: garis pertama } \\
\text { dibentuk oleh pemecah gelombang tsunami yang dibangun di lepas pantai; } \\
\text { baris kedua dengan tanggul pantai/tembok laut yang dibangun di sepanjang } \\
\text { garis pantai dengan hutan pantai atau tanggul berhutan di bagian belakang; } \\
\text { dan pada jalur ketiga dengan membangun jalan layang dan tanggul kereta api } \\
\text { di pedalaman (contoh: mitigasi struktural Jepang) }\end{array}$ & $x$ & V & $\times$ & $x$ & $x$ & $x$ \\
\hline \multicolumn{8}{|c|}{ KESIAPSIAGAAN } \\
\hline [38] & - mempersiapkan jalur evakuasi dan membangun lokasi pengungsian & $x$ & $\mathrm{~V}$ & $x>$ & $x$ & $\mathrm{~V}$ & $x$ \\
\hline [34] & $\begin{array}{l}\text { - penyediaan lokasi penampungan dan rencana evakuasi } \\
\text { - pembangunan tempat penampungan, perangkat peringatan dini, dan } \\
\text { layanan kebutuhan dasar pendukung kehidupan seperti listrik, air bersih, } \\
\text { sanitasi. }\end{array}$ & $\mathrm{V}$ & V & $\sqrt{ }>$ & $x$ & $\sqrt{ }$ & $x$ \\
\hline [18] & $\begin{array}{l}\text { - mengembangkan sistem peringatan, mengidentifikasi rute evakuasi dan } \\
\text { tempat berlindung, dan menjaga sistem komunikasi }\end{array}$ & $\times$ & $x$ & & $x$ & $\sqrt{ }$ & $x$ \\
\hline$[45]$ & - memerlukan infrastruktur tertentu seperti rute dan ruang evakuasi. & $x$ & $\mathrm{~V}$ & & $x$ & $\mathrm{~V}$ & $x$ \\
\hline$[46]$ & pengembangan sistem peringatan dini & $\times$ & V & $\times$ & $x$ & V & $x$ \\
\hline \multicolumn{8}{|c|}{ RESPON } \\
\hline- & Tidak ada kaitan antara perencanaan spasial dan respon dalam MRB & & & & - & & \\
\hline \multicolumn{8}{|c|}{ PEMULIHAN } \\
\hline [44] & $\begin{array}{l}\text { kebijakan pemulihan dengan mempromosikan kombinasi tiga penanggulangan } \\
\text { utama untuk pengurangan risiko tsunami di masa depan, yaitu fasilitas } \\
\text { perlindungan pantai struktural/non-struktural (dengan pertimbangan khusus } \\
\text { dari kontribusi sabuk hijau pantai), peraturan penggunaan lahan dan } \\
\text { manajemen darurat } \\
\text { menyediakan model inovatif yang fokusnya tidak hanya pada menghilangkan } \\
\text { kerusakan tetapi juga harus memperhitungkan pencegahan bencana di masa } \\
\text { depan sebagai prioritas }\end{array}$ & $\mathrm{V}$ & $x$ & $\times$ & $x$ & $\mathrm{~V}$ & $x$ \\
\hline
\end{tabular}

$\mathrm{A}=$ Strategi penataan ruang, $\mathrm{B}=$ Struktur ruang, $\mathrm{C}=$ Pola Ruang, $\mathrm{D}=$ Kawasan strategis, $\mathrm{E}=$ Pemanfaatan ruang, $\mathrm{F}=$ Pengendalian pemanfaaran ruang.

$\mathrm{V}=\mathrm{ada}, \mathrm{X}=$ tidak $\mathrm{ada}$

Dari strategi dan bentuk tindakan MRB yang dapat digolongkan menjadi bagian dari rencana tata ruang pada Tabel 1 di atas, selanjutnya akan dikelompokkan sesuai jenis muatan 
rencana tata ruang yang ada. Langkah ini dilakukan untuk mempermudah penerjemahan ke dalam substansi tata ruang, tanpa melihat sumber literaturnya. Pengelompokan ini juga diikuti dengan reduksi dan penyesuaian kata, dimana sebelumnya terdapat beberapa bahasa literatur dengan maksud yang hampir sama, lebih jelas dapat dilihat pada Tabel 2.

Tabel 2. Muatan rencana tata ruang berdasarkan konsep MRB.

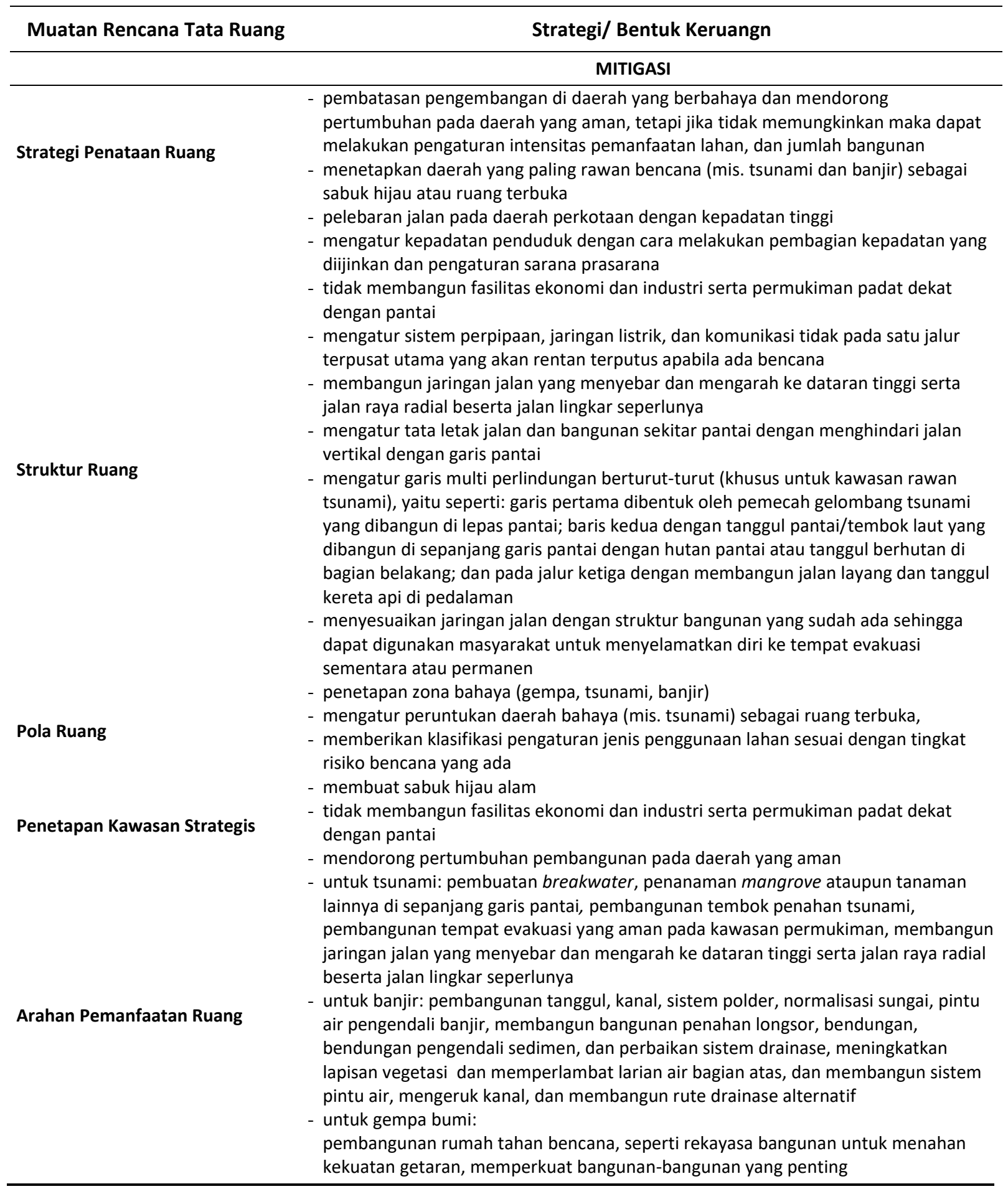




\begin{tabular}{|c|c|}
\hline Muatan Rencana Tata Ruang & Strategi/ Bentuk Keruangn \\
\hline \multirow[t]{2}{*}{ Pengendalian Pemanfaatan Ruang } & $\begin{array}{l}\text { - membatasi pembangunan, } \\
\text { - melarang melakukan pengembangan di area rawan bencana pada masa yang akan } \\
\text { datang, terutama di area dengan sejarah kejadian bencana dan area sangat rawan } \\
\text { - memberikan arahan pembangunan/aktivitas yang diijinkan pada suatu zona } \\
\text { - menentukan building codes dan pembatasan pembangunan pada kawasan risiko } \\
\text { tinggi bencana. } \\
\text { - mengatur persyaratan pembangunan infrastruktur pada daerah bahaya }\end{array}$ \\
\hline & KESIAPSIAGAAN \\
\hline Strategi Penataan Ruang & - mempersiapkan jalur dan lokasi evakuasi serta sistem infrastruktur cadangan \\
\hline Struktur ruang & $\begin{array}{l}\text { - mempersiapkan jalur evakuasi } \\
\text { - mempersiapkan sistem jaringan energi, listrik, dan air bersih cadangan }\end{array}$ \\
\hline Pola ruang & - penyediaan titik lokasi penampungan \\
\hline Pemanfaatan ruang & $\begin{array}{l}\text { - pembangunan tempat penampungan, } \\
\text { - menyediakan perangkat peringatan dini } \\
\text { - menyediakan layanan kebutuhan dasar pendukung kehidupan seperti listrik, air } \\
\text { bersih, sanitasi cadangan }\end{array}$ \\
\hline \multirow[t]{2}{*}{ Pengendalian Pemanfaatan ruang } & - pengaturan sirkulasi dan aksesibilitas sepanjang jalur evakuasi \\
\hline & PEMULIHAN \\
\hline Strategi penataan ruang & $\begin{array}{l}\text { - menyediakan model inovatif yang fokusnya tidak hanya pada menghilangkan } \\
\text { kerusakan tetapi juga harus memperhitungkan pencegahan bencana di masa depan } \\
\text { sebagai prioritas } \\
\text { - kebijakan pemulihan dengan mempromosikan kombinasi tiga penanggulangan } \\
\text { utama untuk pengurangan risiko tsunami di masa depan }\end{array}$ \\
\hline Pemanfaatan ruang & $\begin{array}{l}\text { - menyediakan fasilitas perlindungan pantai struktural/ non-struktural (dengan } \\
\text { pertimbangan khusus dari kontribusi sabuk hijau pantai), peraturan penggunaan } \\
\text { lahan dan manajemen darurat }\end{array}$ \\
\hline
\end{tabular}

Berdasarkan pengelompokan yang telah dilakukan, dapat dilihat bahwa mitigasi bencana memiliki materi yang dapat meliputi semua muatan tata ruang, mulai dari strategi penataan ruang sampai dengan pengendalian pemanfaatan ruang, sedangkan pemulihan hanya meliputi dua muatan yaitu strategi penataan dan pemanfaatan ruang.

Jika dilihat secara menyeluruh mengenai lingkup materi yang diatur pada Tabel 2 di atas, dapat ditemukan pola atau langkah penataan ruang dalam sudut pandang MRB. Hal pertama yang dilakukan yaitu mengetahui kawasan-kawasan yang berpotensi rawan terhadap bencana dari hasil kajian risiko yang kemudian diadopsi dalam penetapan zona bahaya. Kemudian perkembangan pembangunan dapat diarahkan pada zona aman melalui intervensi pengaturan struktur ruang dengan menciptakan pusat-pusat pelayanan dan menata sistem jaringan infrastruktur. Hal ini tentu diikuti dengan penempatan kawasan budidaya pada kawasan yang sesuai. Kepadatan permukiman para daerah rawan pun dapat dikendalikan dengan mengatur batasan kepadatan perumahan serta sarana prasarana ikutannya.

Pada setiap klasifikasi ruang, mulai dari risiko bencana tinggi, risiko rendah, sampai aman terhadap bencana, juga dapat dibangun berbagai sarana prasarana yang dapat mendukung pengamanan terhadap bencana maupun persiapan apabila bencana sewaktu-waktu datang. Terakhir, aturan-aturan penting seperti pelarangan membangun di sempadan sungai dan pantai, pengaturan code bangunan, dan pengaturan kegiatan-kegiatan yang diijinkan pun 
ditetapkan. Selain itu, konsep pencegahan juga diterapkan pada area yang baru dibangun atau kembali dibangun setelah terjadinya bencana untuk meningkatkan ketahanannya.

Strategi dan bentuk MRB yang telah diklasifikasikan sesuai muatan tata ruang di atas masih mencakup semua hal dan bersifat umum. Oleh karena itu, perlu disesuaikan kembali dengan melihat skala perencanaan yang berlaku di Indonesia, mulai dari RTRWN sampai RDTR, agar lebih operasional. Dalam studi ini, penyesuaian skala perencanaan tata ruang terhadap materi MRB yang telah diklasifikasikan sesuai muatannya termasuk dalam tahap analisis kedua. Hasil akhir dari tahap ini ialah tabel kerangka kerja yang dapat digunakan untuk mengevaluasi ketersediaan penerjemahan konsep MRB dalam dokumen rencana tata ruang.

Agar lebih menyederhanakan tabel kerangka kerjanya, maka muatan tata ruang dikelompokkan kembali ke dalam dua bagian sesuai jenisnya, yaitu strategi dan bentuk keruangan, dengan pengelompokkan masing-masing yaitu:

- Strategi, terdiri dari : strategi penataan ruang, pola ruang, struktur ruang, kawasan strategis, pengendalian pemanfaatan ruang;

- Bentuk keruangan, terdiri dari : arahan pemanfaatan ruang.

Khusus untuk RDTR, dimana standar muatannya terdiri atas tujuan penataan BWP, rencana struktur ruang, rencana pola ruang, penetapan Sub BWP yang diprioritaskan penanganannya, dan ketentuan pemanfaatan ruang, maka yang termasuk dalam pengelompokkan disini hanyalah rencana struktur dan pola ruang, serta ketentuan pemanfaatan ruang saja.

Selain itu, jenis strategi dan bentuk yang dijabarkan juga dikembangkan kembali dan diselaraskan dengan produk rencana tata ruang agar lebih mudah digunakan. Hasil penyelarasan inilah yang menjadi interpretasi konsep MRB ke dalam substansi rencana tata ruang. Perlu diketahui bahwa kerangka kerja ini dapat bersifat fleksibel sesuai dengan jenis bencana yang dihadapi, tentu saja dengan pembaharuan pada tahap pengumpulan literaturnya. Hasil rinci kerangka kerja terjemahan konsep MRB dapat dilihat pada Tabel 3.

Tabel 3. Kerangka kerja penilain rencana tata ruang berbasis MRB.

\begin{tabular}{|c|c|c|}
\hline $\begin{array}{c}\text { Level Tata } \\
\text { Ruang }\end{array}$ & Strategi & Bentuk Keruangan \\
\hline \multicolumn{3}{|c|}{ MITIGASI } \\
\hline RTRWN & $\begin{array}{l}\text {-arahan perlindungan DAS } \\
\text {-arahan konservasi hutan } \\
\text {-arahan perlindungan kawasan pesisir } \\
\text {-arahan pusat-pusat kegiatan nasional pada } \\
\text { daerah aman bencana }\end{array}$ & - \\
\hline $\begin{array}{l}\text { RTRWP } \\
\qquad \& \\
\text { RTRWK }\end{array}$ & $\begin{array}{l}\text { - penetapan kawasan rawan bencana gempa } \\
\text { bumi, tsunami, dan banjir } \\
\text {-arahan pengembangan kawasan budidaya pada } \\
\text { daerah aman bencana atau risiko bencana } \\
\text { rendah }\end{array}$ & $\begin{array}{l}\text {-pembangunan jaringan jalan arteri, jalan } \\
\text { layang, atau tol yang tahan bencana } \\
\text {-pelebaran jalan, penataan jaringan jalan, dan } \\
\text { menyediakan jalan lingkar } \\
\text {-penyediaan infrastruktur penahan ombak }\end{array}$ \\
\hline
\end{tabular}




\begin{tabular}{|c|c|c|}
\hline $\begin{array}{c}\text { Level Tata } \\
\text { Ruang }\end{array}$ & Strategi & Bentuk Keruangan \\
\hline & $\begin{array}{l}\text {-konservasi kawasan pantai } \\
\text {-pemenuhan kebutuhan RTH } \\
\text {-arahan pengembangan pusat pelayanan pada } \\
\text { daerah aman bencana atau risiko bencana } \\
\text { rendah } \\
\text {-meningkatkan kapasitas jalan untuk } \\
\text { memudahkan proses evakuasi saat terjadi } \\
\text { bencana } \\
\text {-membatasi kepadatan penduduk pada daerah } \\
\text { rawan bencana } \\
\text {-pemenuhan kebutuhan infrastruktur mitigasi } \\
\text { bencana dan penataan kawasan rawan bencana } \\
\text {-mengatur sistem jaringan prasarana } \\
\text { (transportasi, listrik, telekomunikasi, air bersih, } \\
\text { drainase) pada daerah yang aman bencana } \\
\text {-mengatur sistem jaringan jalan agar dapat } \\
\text { meminimalisir risiko bencana } \\
\text {-mengatur sistem infrastruktur untuk mitigasi } \\
\text { bencana } \\
\text {-menyusun ketentuan umum peraturan zonasi } \\
\text { yang aman terhadap bencana } \\
\text {-melarang pembangunan sarana prasarana } \\
\text { penting di daerah rawan bencana }\end{array}$ & $\begin{array}{l}\text {-penyediaan jaringan listrik dan } \\
\text { telekomunikasi bawah tanah } \\
\text {-penanaman dan penataan mangrove atau } \\
\text { tanaman penahan ombak lainnya } \\
\text {-penyediaan/perbaikan jaringan drainase } \\
\text {-penyediaan ruang terbuka hijau } \\
\text {-penyediaan kolam retensi dan polder } \\
\text {-pembangunan bronjong dan tanggul pada } \\
\text { dinding sungai } \\
\text {-penyediaan sumur resapan } \\
\text {-penyediaan rumah pompa air }\end{array}$ \\
\hline RDTR & $\begin{array}{l}\text {-pengaturan pengembangan pusat pelayanan } \\
\text { kawasan pada daerah aman bencana atau risiko } \\
\text { bencana rendah } \\
\text {-pengaturan zona budidaya pada daerah aman } \\
\text { bencana } \\
\text {-penetapan zona rawan bencana } \\
\text { - pengaturan jaringan jalan, jalur pejalan kaki, } \\
\text { jalur sepeda yang aman bencana } \\
\text {-pengaturan jaringan prasarana (energi, } \\
\text { telekomunikasi, air minum, drainase, limbah) } \\
\text { pada daerah aman bencana } \\
\text {-pengaturan kode bangunan } \\
\text {-pengaturan blok kawasan dengan kepadatan } \\
\text { rendah pada daerah rawan } \\
\text {-aturan zonasi yang aman terhadap bencana (PZ) }\end{array}$ & $\begin{array}{l}\text {-penataan jalur pejalan kaki yang aman } \\
\text {-pembangunan jaringan listrik dan } \\
\text { telekomunikasi bawah tanah } \\
\text {-pembangunan kolam retensi dan polder } \\
\text {-penataan jaringan drainase } \\
\text {-pembuatan bronjong dan tanggul pada } \\
\text { dinding sungai } \\
\text {-pembangunan tembok penangkal ombak dan } \\
\text { sheet pile } \\
\text {-penataan kawasan hutan bakau atau } \\
\text { tanaman penahan ombak lainnya } \\
\text {-penataan RTH } \\
\text {-pembuatan lubang biopori } \\
\text {-penyediaan bak penampungan air hujan } \\
\text {-pelebaran dan penataan jaringan jalan }\end{array}$ \\
\hline
\end{tabular}

KESIAPSIAGAAN

$\begin{array}{cl}\text { RTRWN } & - \\ \text { RTRWP } & \text {-penyediaan jalur evakuasi } \\ \mathbf{\&} & \begin{array}{l}\text {-mengatur/menyediakan sistem jaringan energi, } \\ \text { listrik, dan air bersih cadangan }\end{array} \\ \text { RTRWK } & \text {-penetapan tempat evakuasi sementara dan }\end{array}$

- penambahan daya/ jaringan listrik

- penambahan jaringan telekomunikasi

- pembangunan sarana sanitasi

- penambahan jaringan air bersih 


\begin{tabular}{|c|c|c|}
\hline $\begin{array}{l}\text { Level Tata } \\
\text { Ruang }\end{array}$ & Strategi & Bentuk Keruangan \\
\hline \multirow[t]{2}{*}{ RDTR } & $\begin{array}{l}\text { permanen } \\
\text {-pengaturan sirkulasi dan aksesibilitas sepanjang } \\
\text { jalur evakuasi } \\
\text {-penataan kawasan evakuasi yang sudah ada } \\
\text {-pengaturan sirkulasi dan aksesibilitas sepanjang } \\
\text { jalur evakuasi }\end{array}$ & $\begin{array}{l}\text { - penyediaan shelter } \\
\text { - penataan jalur evakuasi } \\
\text { - penyediaan sarana penyelamatan } \\
\text { - penyediaan early warning system } \\
\text { - pembangunan jaringan perpipaan air bersih } \\
\text { - penataan/pembangunan jaringan listrik dan } \\
\text { BTS/ jaringan telekomunikasi lainnya } \\
\text {-penyediaan alat pendeteksi bencana } \\
\text {-pembangunan MCK umum pada lokasi } \\
\text { evakuasi } \\
\text {-pembangunan shelter } \\
\text { - penataan jalur evakuasi } \\
\text { - pembangunan escape building } \\
\text { - penyediaan posko kesehatan }\end{array}$ \\
\hline & \multicolumn{2}{|c|}{ PEMULIHAN } \\
\hline RTRWN & - & - \\
\hline $\begin{array}{l}\text { RTRWP } \\
\qquad \& \\
\text { RTRWK }\end{array}$ & $\begin{array}{l}\text {-arahan permukiman baru yang aman bencana } \\
\text {-rehabilitasi kawasan }\end{array}$ & $\begin{array}{l}\text { - penataan kawasan pasca bencana } \\
\text { - penyediaan infrastruktur, sarana, dan } \\
\text { prasarana pada kawasan pengembangan } \\
\text { baru }\end{array}$ \\
\hline RDTR & $\begin{array}{l}\text {-penataan kawasan baru pasca bencana } \\
\text {-penataan permukiman baru yang aman bencana }\end{array}$ & $\begin{array}{l}\text {-pembangunan prasarana dan fasilitas pada } \\
\text { lokasi baru } \\
\text {-penyediaan pemakaman masal }\end{array}$ \\
\hline
\end{tabular}

Secara umum, penerjemahan strategi dan bentuk MBR dalam substansi rancana tata ruang hampir sama pada tiap jenjang perencanaannya, hanya saja luasan wilayah perencanaan dan juga skala penyajian peta turut mempengaruhi kedetailan isi substansi yang diatur.

Terdapat tiga hal penting yang dapat dilihat dari tabel kerangka kerja di atas. Pertama, khususnya pada skala nasional, konsep MRB berupa mitigasi hanya dapat diterapkan dalam strategi. Bahkan tidak terdapat konsep kesiapsiagaan dan pemulihan yang dapat dimasukkan ke dalam kerangka kerja pada taraf ini. Hal ini dapat disebabkan oleh skala perencanaan yang terlalu luas, sedangkan bencana dan penanggulangannya sangat berpengaruh pada lokasi terjadinya, yaitu pada level lokal.

Kedua, pada level provinsi dan kabupaten/kota, terdapat banyak strategi dan bentuk keruangan yang dapat diterjemahkan. Mulai dari berbagai strategi penetapan kawasan, pengaturan fungsi kawasan lindung dan budidaya, pengaturan kepadatan, sampai pengendalian pembangunan sarana prasarana di kawasan rawan bencana. Begitu juga pada bentuk keruangannya, berbagai program dapat diterapkan seperti pembangunan tanggul, pelebaran jalan, perbaikan drainase, penyediaan ruang terbuka hijau, penyediaan jalur evakuasi, dan lain-lain. Hal ini tidak hanya berlaku pada komponen mitigasi, tetapi juga pada 
kesiapsiagaan dan pemulihan. Strategi dan bentuk keruangan MRB ini dapat langsung berpengaruh pada konsep perencanaan tata ruang wilayahnya secara keseluruhan.

Ketiga, pada level rencana detail juga banyak strategi dan bentuk keruangan yang dapat dilakukan. Namun dalam hal ini lebih banyak pada penataan dan pengaturan pembangunan yang sifatnya lebih operasional dilapangan. Bentuk-bentuk keruangan yang diterapkan dapat lebih detail dan rinci jenisnya. Pada komponen kesiapsiagaan pun dapat lebih fokus dilakukan yaitu melalui penataan kawasan khusus evakuasi dan menyiapkan berbagai infrastruktur sebagai cadangan apabila bencana merusak infrastruktur dasar perkotaan lainnya.

Dari berbagai temuan tersebut maka dapat disimpulkan bahwa kerangka kerja ini akan lebih bermanfaat ketika menilai produk rencana tata ruang pada level provinsi dan kabupaten/ kota.

\section{Kesimpulan}

Studi ini mengedepankan kajian literatur dalam rangka mengembangkan kerangka kerja untuk melakukan penilaian rencana tata ruang dalam perspektif MRB. Kerangka kerja tersebut dirinci berdasarkan level perencanaan dari nasional sampai bagian wilayah kabupaten/kota, serta ditinjau dari dua sisi yaitu strategi dan bentuk keruangan. Materi yang termuat dalam kerangka kerja dipengaruhi oleh jenis kebencanaan yang ada pada suatu wilayah perencanaan. Disisi lain, substansi tata ruang sendiri sangat komprehensif sehingga banyak aspek dalam rencana tata ruang yang harus mempertimbangkan faktor kebencanaan dalam proses perumusannya.

Kerangka kerja ini lebih operasional digunakan pada level provinsi dan kabupaten/kota berdasarkan strategi dan bentuk keruangan yang dapat dilakukan. Selain itu, komponen MRB berupa mitigasi merupakan komponen yang paling sesuai penerapannya dalam rencana tata ruang dibandingkan kesiapsiagaan dan pemulihan, sedangkan tindakan respon tidak dalam dituangkan secara langsung ke dalam berbagai muatan rencana tata ruang.

Kerangka kerja teoritis yang dirumuskan ini diharapkan dapat menjadi panduan dalam menilai atau mengevaluasi kebijakan tata ruang yang sudah ada. Selain itu, juga dapat digunakan dalam mengintegrasikan konsep MRB dengan rencana tata ruang pada proses penyusunannya.

\section{Referensi}

[1] Kusmiati C Y 2005 Menuju Perbaikan Manajemen Penanggulangan Bencana di Indonesia Jurnal Administrasi Publik 42 pp 185-208 Diakses dari http://journal.unpar.ac.id/index.php/JAP/article/view/1554

[2] Edyanto C B H 2011 Analisa Kebijakan Penataan Ruang Untuk Kawasan Rawan Tsunami Di Wilayah Pesisir Jurnal Teknologi Lingkungan 123 pp 309-18 DOI: 10.29122/jtl.v12i3.1240

[3] Buchori I, Sugiri A, Mussadun M, Wadley D dan Liu Y 2017 International Journal of 
Disaster Risk Reduction A predictive model to assess spatial planning in addressing hydro- meteorological hazards: A case study of Semarang City, Indonesia Int J Disaster Risk Reduct $24 \quad \mathrm{pp} \quad 1-568$ Diakses dari https://www.sciencedirect.com/journal/international-journal-of-disaster-riskreduction/vol/24/suppl/C

[4] Smets P dan Lindert P 2016 Sustainable housing and the urban poor International Journal of Urban Sustainable Development $8 \begin{array}{lllll}\mathbf{8} & 1 & \mathrm{pp} & 1-9 & \mathrm{DOI}\end{array}$ 10.1080/19463138.2016.1168825

[5] Amaratunga D, Malalgoda C, Haigh R, Panda A dan Rahayu H 2018 Sound Practices of Disaster Risk Reduction at Local Level Procedia Engineering Elsevier 212 pp 1163-70 DOI: 10.1016/j.proeng 2018.01.150

[6] Burby R J, Deyle R E, Godschalk D R dan Olshansky RB 2000 Creating Hazard Resilient Communities Through Land-Use Planning Natural Hazards Review 12 pp 99-106 Diakses dari https://ascelibrary.org/doi/10.1061/\%28ASCE\%2915276988\%282000\%291\%3A2\%2899\%29

[7] Greiving S dan Fleischhauer M 2006 Spatial Planning Response Towards Natural and Technological Hazard Geological Survey of Finland (Special Paper) 42 pp 109-23 Diakses http://citeseerx.ist.psu.edu/viewdoc/download?doi=10.1.1.527.6780\&rep=rep1\&ty pe=pdf

[8] Sutanta H, Bishop I D dan Rajabifard A 2010 Integrating Spatial Planning and Disaster Risk Reduction at the Local Level in The Context of Spatially Enabled Government Spatial Enabling Soc Res Emerg Trends Crit Assess 1 pp 55-68 Diakses dari https://minerva-

access.unimelb.edu.au/bitstream/handle/11343/28949/265594_Integrating+Spatial +Planning+and+Disaster+Risk+Reduction+at+the+Local+Level+in+the+Context+of+S patially+Enable+Government.pdf;jsessionid=5E051E2024A2B44C3CC7C69B842AC35 $\mathrm{F}$ ?sequence $=1$

[9] Glavovic B C 2010 The Role Of Land-Use Planning In Disaster Risk Reduction: An Introduction to Perspectives from Australasia Austalasian Journal Disaster and Trauma Studies $2010 \quad 1 \quad \mathrm{pp} \quad 1-22 \quad$ Diakses dari https://www.researchgate.net/publication/232581114_The_role_of_landuse_planning_in_disaster_risk_reduction_An_introduction_to_perspectives_from_ Australasia

[10] Bajec N L 2011 Integrating Climate Change Adaptation Policies In Spatial Development Planning In Serbia (A Challenging Task Ahead) Spatium International Preview 58324 pp 1-8 DOI: 10.2298/SPAT1124001L

[11] Suroso D S A dan Firman T 2018 The role of spatial planning in reducing exposure towards impacts of global sea level rise case study: Northern coast of Java, Indonesia Ocean Coast Management 153 pp 84-97 DOI: 10.1016/j.ocecoaman.2017.12.007

[12] Zakina N dan Pamungkas A 2018 Penilaian Integrasi Manajemen Risiko Bencana ke dalam Proses Penyusunan Rencana Tata Ruang Kota Surabaya Jurnal Teknik ITS 72 
pp 2337-3539 DOI: 10.12962/j23373539.v7i2.33656

[13] Burby R J, Beatley T, Berke P R, Deyle R E, French S P, Godschalk D R, ... Platt R H 1999 Unleashing The Power Of Planning to Create Disaster-Resistant Communities Journal of the American Planning Association 653 pp 247-58 DOI: 10.1080/01944369908976055

[14] Sengezer B and Koç E 2005 A Critical Analysis Of Earthquakes And Urban Planning in Turkey Disasters 292 pp 171-94 DOI: 10.1111/j.0361-3666.2005.00279.x.

[15] Sutanta H 2012 Spatial Planning Support System for an Integrated Approach to Disaster Risk Reduction Thesis The University of Melbourne Diakses dari https://minerva-access.unimelb.edu.au/handle/11343/37854

[16] Baas S, Rasmasamy S, Pryck J dan Battista F 2008 Disaster Risk Management Systems Analysis: A Guide Book (Rome: Food and Agriculture Organization of the United Nations) Diakses dari http://www.fao.org/3/a-i0304e.pdf

[17] Mitchell T 2003 An Operational Framework for Mainstreaming Disaster Risk Reduction Disaster Studies Working Paper 8 Diakses dari http://citeseerx.ist.psu.edu/viewdoc/download?doi=10.1.1.483.1125\&rep=rep1\&ty pe=pdf

[18] Mojtahedi M, Oo B L 2017 Critical Attributes for Proactive Engagement of Stakeholders In Disaster Risk Management International Journal of Disaster Risk Reduction 21 pp 35-43. DOI: 10.1016/j.ijdrr.2016.10.017

[19] Wamsler C 2006 Mainstreaming Risk Reduction In Urban Planning And Housing: A Challenge for International Aid Organisations Disasters 302 pp 151-77 DOI: 10.1111/j.0361-3666.2006.00313.x.

[20] Wang J J 2012 Integrated Model Combined Land-Use Planning and Disaster Management: The Structure, Context and Contents Disaster Prevention and Management 211 pp 110-23 DOI: 10.1108/09653561211202746

[21] Fahmi F, Timms P dan Shepherd S 2014 Integrating Disaster Mitigation Strategies in Land Use and Transport Plan Interaction Procedia - Social and Behavioral Sciences 111 pp 488-97 DOI: 10.1016/j.sbspro.2014.01.082

[22] Ran J dan Nedovic-Budic Z 2016 Integrating spatial planning and flood risk management: A new conceptual framework for the spatially integrated policy infrastructure Computers, Environment and Urban Systems 57 pp 68-79 DOI: 10.1016/j.compenvurbsys.2016.01.008

[23] Godschalk D R, Kaiser E J dan Berke P 1999 Integrating Hazard Mitigation and Local Land Use Planning Diakses dari https://www.researchgate.net/publication/297253266_Integrating_hazard_mitigati on_and_local_land-use_planning

[24] Suryanta J, Nahib I 2016 Kajian Spasial Evaluasi Rencana Tata Ruang Berbasis Kebencanaan Di Kabupaten Kudus Provinsi Jawa Tengah Majalah IImiah Globe 181 pp 33-42 Diakses dari https://d1wqtxts1xzle7.cloudfront.net/59080261/392-635-1SM20190429-38509-neug8k.pdf?1556591428=\&response-contentdisposition=inline\%3B+filename\%3DKAJIAN_SPASIAL_EVALUASI_RENCANA_TATA_R UA.pdf\&Expires $=1594757108 \&$ Signature $=f R c N \sim D F Z S c V y h h d r z y H y T 7 E 7 L g e r L j 5 y U Z Q$ 
2yaViG itrQ--YYg0aNjavbsGDBYOOX7bY3PJLAWc8rM-

vJwEuqg|I9tLGCRDQzHJPvsPiOJCRg9xnD6vBBHmkOmfXU42luC1ciOZwh7F20eLsuhbE OpC7bjjcCzQJKaxqqK6Iz4EaMCtD2y4w6 MH9Yi1xqHm5VadJTFJKqc99gcboXMw6bp 56YAYGsZKrr3PDG8PSqE1sMGHxRCpSveQFrsckDekSBZ9rQH9zlai8bH23gA5fJCPanl0 v95R3bdyaQnYNGa4TmYVVSFnG2W-94Tz4H76yMczXmMNbaQp5p5HcJ8A_\&KeyPair-Id=APKAJLOHF5GGSLRBV4ZA

[25] Greiving S, Fleischhauer M dan Wanczura S 2006 Management of Natural Hazards in Europe: The Role of Spatial Planning in Selected EU Member States Journal of Environmental Planning and Management $49 \quad 5$ pp 739-57 DOI: 10.1080/09640560600850044

[26] Peraturan Menteri Agraria dan Tata Ruang/ Kepala Badan Pertanahan Nasional RI Nomor 1 tahun 2018 tentang Pedoman Penyusunan Rencana Tata Ruang Wilayah Provinsi, Kabupaten dan Kota Berita Negara RI Tahun 2018 No.394 Diakses dari https://peraturan.bpk.go.id/Home/Details/103682/permen-agrariakepala-bpn-no1-tahun-2018

[27] Peraturan Menteri Agraria dan Tata Ruang/ Kepala Badan Pertanahan Nasional RI Nomor 16 Tahun 2018 tentang Pedoman Penyusunan Rencana Detail Tata Ruang dan Peraturan Zonasi Kabupaten/ Kota Berita Acara RI Tahun 2018 Diakses dari http://ditjenpp.kemenkumham.go.id/arsip/bn/2018/bn1308-2018.pdf

[28] Peraturan Pemerintah RI Nomor 26 Tahun 2008 tentang Rencana Tata Ruang Wilayah Nasional Lembaran Negara RI Tahun 2008 No. 48 Diakses dari http://pelayanan.jakarta.go.id/download/regulasi/peraturan-pemerintah-nomor26-tahun-2008-tentang-rencana-tata-ruang-wilayah-nasional.pdf

[29] Fleischhauer M 2008 The Role of Spatial Planning In Strengthening Urban Resilience Resilience of Cities to Terorist and other Threats Springer Publisher pp 273-98 DOI: 10.1007/978-1-4020-8489-8_14

[30] Undang-Undang Republik Indonesia Nomor 26 tahun 2007 tentang Penataan Ruang Diakses dari https://www.gitews.org/tsunamikit/en/E6/further_resources/national_level/undang_undang/UU\%20262007_Penataan\%20Ruang.pdf

[31] Hudalah D dan Woltjer J 2007 Spatial Planning System In Transitional Indonesia Journal International Planning Studies 123 pp 291-303 DOI: 10.1080/13563470701640176

[32] Coburn A W, Spence R J S dan Pomonis A 1994 Mitigasi Bencana (Edisi Kedua) (United Kingdom: Program Pelatihan Manajemen Bencana) Diakses dari https://rovicky.files.wordpress.com/2009/10/mitigasi-bencana.pdf

[33] Saunders W S A dan Kilvington M 2016 Innovative Land Use Planning for Natural Hazard Risk Reduction: A Consequence-driven Approach from New Zealand International Journal of Disaster Risk Reduction 18 pp 244-55 DOI: 10.1016/j.ijdrr.2016.07.002

[34] Barton C C 2009 Disaster Preparedness and Management Information Resources in Toxicology (Fourth Edition) Academic P Elsevier 22 pp 195-201 Diakses dari https://linkinghub.elsevier.com/retrieve/pii/B9780123735935000227

[35] NOAA, USGS, FEMA dan NSF 2001 Designing for Tsunamis: Seven Principles for 
Planning and Designing for Tsunami Hazards (National Tsunam Hazard Mitigation Program) Diakses dari https://nws.weather.gov/nthmp/documents/designingfortsunamis.pdf

[36] Diposaptono S 2003 Mitigasi Bencana Alam di Wilayah Pesisir Dalam Kerangka Pengelolaan Wilayah Pesisir Terpadu di Indonesia Jurnal ALAMI: Air, Lahan, Lingkungan, dan Mitigasi Bencana 82 pp $1-8$ Diakses dari http://ejurnal.bppt.go.id/index.php/ALAMI_ALLM/article/view/1683

[37] Saruksuk J H 2006 Konsep Jaringan Jalan Pada Kota Yang Rawan Bencana Gempa dan Tsunami (Studi Kasus Kota Sibolga) Thesis Diakses dari http://eprints.undip.ac.id/15684/

[38] Cahanar P 2005 Bencana Gempa dan Tsunami. Nanggroe Aceh Darussalam \& Sumatera Utara (Jakarta: Penerbit Buku Kompas)

[39] Fleischhauer M, Greiving S dan Schlusemann B 2005 Multi-risk Assessment of Spatially Relevant Hazards in Europe ESMG Symposium pp 1-14 Diakses dari https://www.researchgate.net/profile/Philipp_Schmidt-

Thome/publication/255667455_Multi-

risk_assessment_of_spatially_relevant_hazards_in_Europe/links/58b6c7a2a6fdcc2d 14d6c5e6/Multi-risk-assessment-of-spatially-relevant-hazards-in-Europe.pdf

[40] Ramli S dan Djajaningrat H 2010 Pedoman Praktis Manajemen Bencana (Jakarta: Dian Rakyat)

[41] Chang H-S dan Hsieh H-Y 2013 An Exploratory Study on Land Use Planning of Disaster Prevention: A Case Study of Kaohsiung New Town Procedia Environmental Sciences 17 pp 382-91 DOI: 10.1016/j.proenv.2013.02.051

[42] Mirza F 2015 Disaster Mitigation Approach of Urban Green Structure Concept In Coastal Settlement DIMENSI - Journal of Architecture and Built Environment 422 pp 51-8 DOI: 10.9744/dimensi.42.2.51-58

[43] Burby R J dan French S P 2007 Coping With Floods: The Land Use Management Paradox Journal of the American Planning Association 473 pp 289-300 DOI: 10.1080/01944368108976511

[44] Strusińska-Correia A 2017 Tsunami Mitigation In Japan After The 2011 Tōhoku Tsunami International Journal of Disaster Risk Reduction 22 pp 397-411 DOI: 10.1016/j.ijdrr.2017.02.001

[45] Kötter T 2013 Prevention of Environmental Disasters by Spatial Planning and Land Management 2nd FIG Reg Conf pp 1-6 Diakses dari https://www.gdrc.org/uem/disasters/disenvi/koetter.pdf

[46] Undang-Undang Republik Indonesia Nomor 24 Tahun 2007 Tentang Penanggulangan Bencana Diakses dari https://bnpb.go.id/ppid/file/UU_24_2007.pdf 